\title{
Assessment of trap efficiency of the reservoirs in the Siret Basin (Romania)
}

\author{
Florin OBREJA ${ }^{1,2}$ \\ 1 "Stefan cel Mare“ University of Suceava, Geography Department \\ 2 "Siret" Water Administration, Bacau \\ * Correspondence to: Florin Obreja, „Stefan cel Mare“ University of Suceava, Romania. E-mail: florin_obreja@yahoo.com \\ (C2012 University of Suceava and GeoConcept. All rights reserved \\ doi: 10.4316/GEOREVIEW.2012.21.1.60
}

\section{(4) GEOREVIEW}

\section{Article history}

Received: July 2012

Received in revised form:

October 2012

Accepted: December 2012

Available online: January

2013

\begin{abstract}
In this paper we calculate the trap efficiency of the reservoirs in the Siret Basin and we make also a briefly analysis to show the way this reservoirs influence the sediment discharge of the rivers by sedimentation. Trap efficiency (TE) is an indicator and parameter of sediment yield from upstream and of sedimentation rate from the reservoirs. In consequence we calculate for 14 reservoirs in the Siret Basin this parameter. The values of TE vary between $42-98 \%$ and correlates very well with the capacity of the reservoirs. In reservoirs with the high capacity the values approach to $100 \%$ while in small reservoirs, the value of TE is decreasing. Capacity and operating mode lakes are important factors controlling the degree of retention of sediment from the source area. Sedimentation within reservoirs is a problem as it decrease the storage capacity and, hence, makes the structure less efficient. For small reservoirs, sedimentation can become a severe problem as the rate of siltation is generally much higher in comparison to large dams.
\end{abstract}

KEY WORDS: sediment load, sedimentation rate, dams, soil erosion, Romania

\section{Introduction}

Reservoir sedimentation is a serious consequence of soil erosion with large environmental and economical implications. On the other hand, reservoir sedimentation also provides valuable information on erosion problems and sediment transport within a drainage basin. $A$ reservoir can be considered as a large scale experiment, as the outlet of a giant erosion plot (Verstraeten and Poesen, 2000).

The objective of this paper is to indicate how the reservoirs from the Siret Basin influence the sediment discharge of the rivers by sedimentation and to calculate the trap efficiency of the reservoirs from this basin which indicate the capacity of these reservoirs to trap sediments.

The problem of the reservoir silting in Romania and also in the Siret River Basin was a very important research topic for many scientific papers (Ciaglic et.al, 1973; lonescu, 1980; Zavati and 
Giurma, 1987; Apopei et.al, 1988; Ichim and Rădoane, 1986; Roşca, 1987; Roșca and Mițurcă, 1988; Pricop et.al, 1988; Roşca and Teodor, 1990; Şerban and Teodor, 1992; Scortov and Armencea, 1992; Olariu, 1992; Olariu and Gheorghe, 1999; Purnavel, 1999; Gâștescu et.al, 2003; Rădoane and Rădoane, 2004, 2005).

Reservoir sedimentation has been also the subject of numerous studies and research in international bibliography (Walling, 1983, 1997, 1999, 2009; Verstraeten, Poesen, 2002; Syvitski et.al, 2003, 2005; Syvitski, Milliman, 2007; de Vente et.al, 2007). For this paper we must also make reference to sediment trap efficiency. This parameter was extensively studied. The first has paid special attention to this parameter was Brown (1943) who developed a model. It was then followed by others who have contributed to the knowledge of trap efficiency - TE (Churchill, 1948; Brune, 1953; Vanoni, 1977; Heinemann, 1981) and some of them even made improvements to the model (Churchill, 1948; Brune, 1953; Heinemann, 1981). Verstraeten and Poesen (2000) made a synthesis of the most used methods for calculating TE both in terms of empirical models and theoretical models.

\section{The area of investigation}

The Siret River is the biggest river in Romania. It springs from the Paleogene flysch of the Wooded Carpathians (in Ukraine) at an altitude of approximately $1238 \mathrm{~m}$ (Ujvari, 1972) and drains, within its catchment the central-eastern part of the Eastern Carpathians and a part of the South-Eastern Carpathians, the Moldavian Sub-Carpathians and the northern part of SouthEastern Sub-Carpathians, the Moldavian Plateau and the Lower Siret Plain. The catchment area of the Siret River covers an area of $44871 \mathrm{~km}^{2}$ from which $42890 \mathrm{~km}^{2}$ in Romania. The total length of this river in Romania is $548 \mathrm{~km}$, while there are another $110 \mathrm{~km}$ from its springs to the point it enters Romania.

The main relief lines decrease in height from west to east and from north to south. The morphographical and morphometrical features depend on lithology. This way in the Carpathians area, from west to east, there aligns the main morphological units (Olariu et.al, 2009):

-Volcanic mountains, with massive forms and hard rocks. In this area the runoff is high (15- 20 $\left.\mathrm{l} / \mathrm{s} / \mathrm{km}^{2}\right)$ and the sediment yield is low $(0,5-0,7 \mathrm{t} / \mathrm{ha} / \mathrm{yr})$.

-Crystalline mountains, also with massive forms, and very high, because of the hard rocks, and with limestone intrusion. The runoff is still high $\left(12-16 \mathrm{l} / \mathrm{s} / \mathrm{km}^{2}\right)$ while the sediment yield is low $(0,8-1,2 \mathrm{t} / \mathrm{ha} / \mathrm{yr})$.

-Flysch Mountains are characterized by a great lithological variability, because of the overthrust layers. Here the runoff has values between $8-14 \mathrm{l} / \mathrm{s} / \mathrm{km}^{2}$, and the sediment yield become high (20 - $25 \mathrm{t} / \mathrm{ha}$ /yr in the South-Eastern Carpathians).

The Sub-Carpathians are located on the eastern part of the Carpathians, characterized by the presence of some depressions bounded by anticline hills. In this area the runoff is between $8-10$ $\mathrm{l} / \mathrm{s} / \mathrm{km}^{2}$, and the sediment yield between $5-15 \mathrm{t} / \mathrm{ha} / \mathrm{an}$, but there are a lot of variations.

The main relief units from the platform region are the Moldavian Plateau, the Lower Siret Plain and the north-east part of the Baragan Plain. In the plateau, the runoff has values between $2-6$ $\mathrm{l} / \mathrm{s} / \mathrm{km}^{2}$, and the sediment yield between, $2-5 \mathrm{t} / \mathrm{ha} / \mathrm{yr}$. In the plain area the values of the runoff and the sediment yield are much smaller. 
During 1960-2001 in the Siret Basin were constructed 35 dams with a height of at least $10 \mathrm{~m}$ behind which were made reservoirs for various purposes which include water supply to municipalities, irrigation, electricity or fish and leisure (Rădoane and Rădoane, 2004, 2005). Siret Basin is characterized by the highest use of hydrological potential in Romania, resulted in the number of reservoirs designed and put into operation. Among the other rivers and river basins in Romania, only Olt River poses a much bigger number of reservoirs than Siret (Dăscălescu, 2000). Regarding capacity of the reservoirs in the Siret Basin there is a dominance of small reservoirs with capacities below 20 million $\mathrm{m}^{3}$. Only one reservoir has capacity over 200 million $\mathrm{m}^{3}$ - Izvorul Muntelui on Bistrita River.

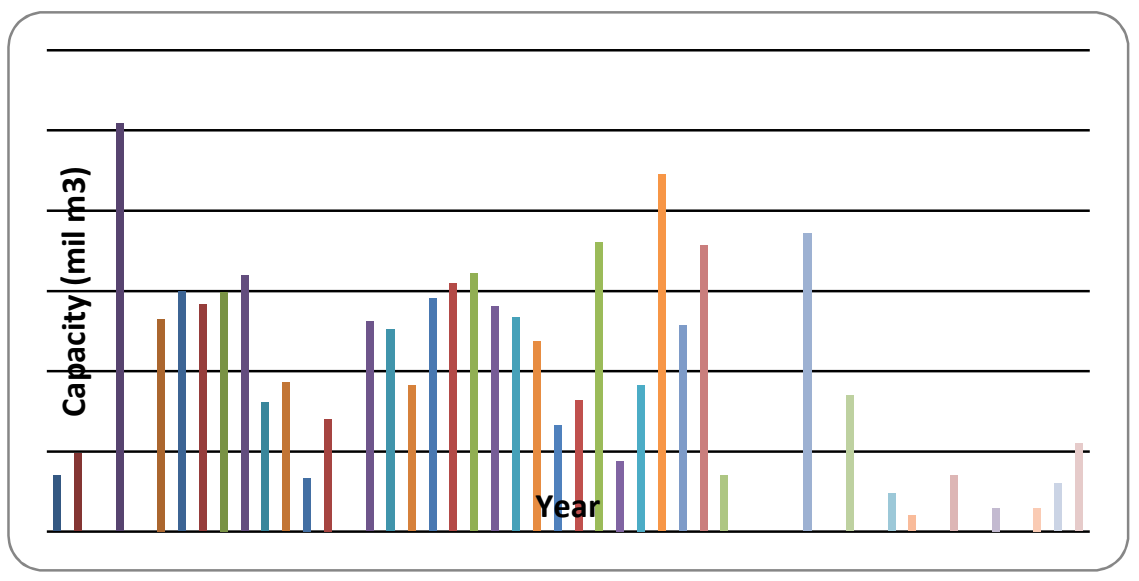

Figure 1. Changes of capacity of reservoirs in the Siret Basin in 1957-2007. This figure is available in colour online at www.georeview.ro.

Capacity and operating mode lakes are important factors controlling the degree of retention of silt from the source area. As we mentioned above sedimentation within reservoirs is a problem as it decrease the storage capacity and, hence, makes the structure less efficient. For small reservoirs, sedimentation can become a severe problem as the rate of siltation is generally much higher in comparison to large dams (Rădoane and Rădoane, 2005).

Table 1. Total reservoir capacity in catchments of main tributaries of the Siret River (2012)

\begin{tabular}{lc}
\hline River & Reservoir storage $\left(\mathrm{mil} \mathrm{m}^{\mathbf{3}}\right)$ \\
\hline SIRET & 442 \\
SUCEAVA & 7.7 \\
SOMUZU MARE & 25.0 \\
SOMUZU MIC & 3.0 \\
MOLDOVA & 1.0 \\
VALEA NEAGRA & 5.9 \\
BISTRITA & 1280 \\
TROTUS & 104 \\
PUTNA & 0 \\
BARLAD & 95 \\
BUZAU & 170 \\
\hline TOTAL & $\mathbf{2 1 3 4}$ \\
\hline
\end{tabular}




\section{Data sets and methods}

Because this article refers to the trap efficiency of the reservoirs in the Siret Basin we have used the database of Siret Water Administration which consists from bathymetric measurements made over time on reservoirs from this institution (volumetric curves, catchment area, and surface of the reservoir, the initial volumes, and the last measured volume). Database that we had was completed with values from other lakes in Siret Basin, from previous studies referring to Barlad Basin and Buzau Basin (main tributaries of Siret River).

To perform an analysis of trap efficiency of reservoirs in the Siret Basin as well as how these reservoirs affect the sediment and water discharge of the rivers by retaining significant quantities, two methods were used for these topics : calculating sediment trap efficiency of the reservoirs (TE) and double mass curves (plots, Walling, 1997).

Sediment trap efficiency (TE) is the proportion of the incoming sediment that is deposited, or trapped, in a reservoir or pond. In situation when sediment data downstream the reservoir is available this parameter is effective in calculating the sediment yield of the upstream catchment of the reservoir. The TE of reservoirs and ponds is dependent on several parameters (an overview of these processes taking places in a reservoir is given by Heinemann, 1981, cited by Verstraeten and Poesen, 2000). Since TE is dependent on the amount of sediment deposited, parameters controlling the sedimentation process are very important.

Verstraeten and Poesen (2000) make a briefly overview of the high number of the factors that influence the trap efficiency of pond and reservoirs. Starting from the fractions of incoming sediments they relate this parameter with the settling velocity of sediment particles and with the retention time of runoff and sediment particles. They also marked the importance of the incoming sediment characteristics (particle size distribution), inflow characteristics (runoff volume, peak discharge, base flow) and pond characteristics (pond typology, surface area, shape, outlet dimension, outlet type, location of the outlet, initial storage volume).

Taking in consideration the many parameters that influences the sedimentation process and, hence the TE of reservoirs and ponds, it is very difficult to predict TE in a simple manner. The most accurate predictions will be those based on theoretical relations that incorporate all the influencing factors. However this requires not only the use of complex models but also the availability of a great deal of input data. Simple models relating TE to a single reservoir parameter are, on the other hand, easy to implement but are far less accurate (Verstraeten and Poesen, 2000).

Different empirical relations have been developed to estimate the trap efficiency. Usually the relation proposed by Brown (eq. 1)(Brown, 1943) and Brune (eq. 2)(Brune, 1953) are applied, as these relations are suited for large reservoirs, and is relatively easy to apply.

$$
\begin{aligned}
& \text { Brown relation (1943) } \\
& \mathrm{TE}=100 *\left\{1-1 /\left[1+\mathrm{D}^{*}(\mathrm{C} / \mathrm{A})\right]\right\}
\end{aligned}
$$

In this relation TE, stands for trap efficiency (\%), C for the capacity of the reservoir $\left(\mathrm{m}^{3}\right)$ and A for the drainage are of the basin $\left(\mathrm{km}^{2}\right)$. D is a constant between 0.046 and 1 , with a mean value of 0.1 and depends on the reservoir type. Brown (1943) suggest that values for D are close to 1 (i.e. 
high TE) for reservoirs in regions with smaller and more variable runoff and for those that hold back and store flood flows.

Brune (1953) replaced the C/A (capacity/catchment area) ratio with C/I (capacity/inflow) ratio because he stated that in the catchments with the same area the hydrological characteristics might be different.

$$
\begin{aligned}
& \text { Brune relation (1953) } \\
& \mathrm{TE}=100 *\left\{1-1 /\left[1+\mathrm{D}^{*}(\mathrm{C} / \mathrm{I})\right]\right\}
\end{aligned}
$$

Even if the second relation is more accurate we used both in our study because for some reservoirs we didn't have inflow values.

We also have to mention that if a reservoir had in its close upstream another reservoir we couldn't calculate the trap efficiency (TE) of the downstream reservoir because of the influenced regime of the water and sediment inflow.

Double mass curves (plots) is a tool frequently used to identify changes in the sediment response of a river (Walling 1997), using annual values of water and sediment discharge, transformed in runoff $\left(\mathrm{m}^{3}\right)$ and sediment load $(\mathrm{t})$. This method represents a plot (figure 2 and 3 ) between cumulative values of the parameters mention above and can be explaining in three ways:

- break in line above in the double mass plots, suggests that the controls in the catchment modified with the increasing of the sediment and/or decreasing the runoff.

- break in line below in the double mass plots, suggests that the controls from the catchment modified with de decreasing of the sediment transport and/or increasing of the runoff.

- straight line (no clear break in the double mass plots), suggests that both the runoff and sediment have responded to similar controls.

\section{Results}

As is well known building dams have a significant impact on the hydrological regime of the river and river bed geomorphology. Various authors have indicated this with reference to reservoir silting and river processes occurring downstream of dams, namely deepening riverbeds (Ichim and Rădoane, 1986), which is not subject of this study. In the following we will realize an analysis of the sedimentation process in reservoirs from the Siret Basin as an effect in sediment discharge regime and the evolution of this process in terms of the percentage of sediment retention (trap efficiency - TE).

The first issue that we will consider is the time evolution of the sediment transport and the way of evolution of this parameter corresponding with runoff. From the Siret Basin for this analysis we only had data for the Siret River. For the gauging stations considered - Hutani, Lespezi, Dragesti, Lungoci - we need to mention some very important issues. Three of them are located downstream of major confluences with important tributaries of the Siret: Lespezi downstream of the confluence with the Suceava River $\left(F=2400 \mathrm{~km}^{2}\right.$; Qmed $=16.9 \mathrm{~m}^{3} / \mathrm{s}$; Rmed $=14.7 \mathrm{~kg} / \mathrm{s})$, Dragesti downstream of the confluence with Moldova $\left(\mathrm{F}=4100 \mathrm{~km}^{2}\right.$; Qmed $=32.6 \mathrm{~m}^{3} / \mathrm{s} ;$ Rmed $=37.2 \mathrm{~kg} / \mathrm{s}$ ) and Lungoci, downstream of the confluence with Putna River $\left(F=2500 \mathrm{~km}^{2} ;\right.$ Qmed $\left.=9.07 \mathrm{~m}^{3} / \mathrm{s} ; \mathrm{Rmed}=84.5 \mathrm{~kg} / \mathrm{s}\right)$. Also two of these four hydrometric stations are located downstream of some reservoirs: Hutani downstream of the 
Bucecea Reservoir ( $C=7$ mil. $\mathrm{m}^{3}$ ) and Lungoci downstream of Movileni Reservoir ( $\mathrm{C}=10 \mathrm{mil}$. $\left.m^{3}\right)$.
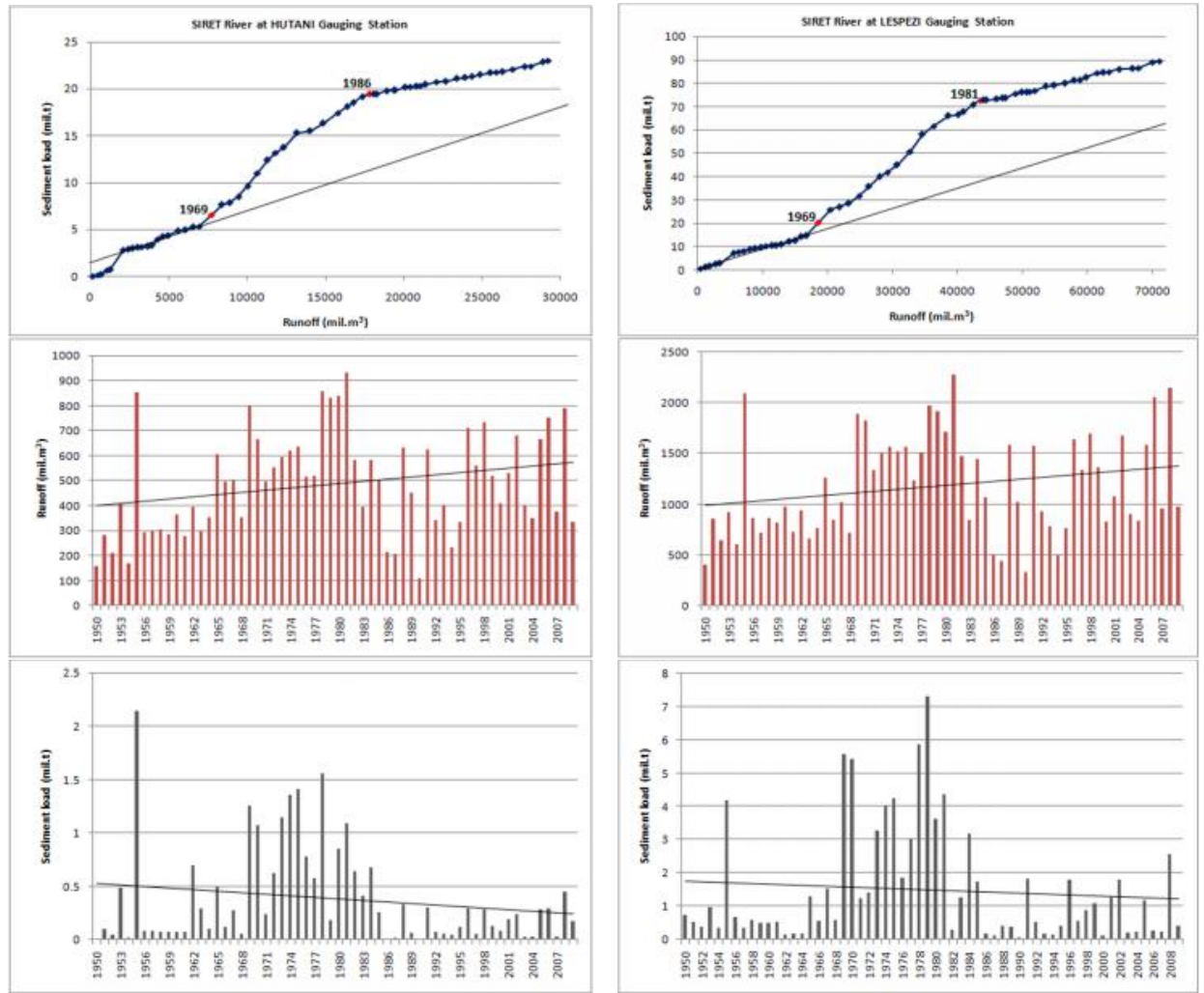

Figure 2. Double mass curves of sediments and runoff on the Siret River at Hutani and Lespezi during 1950-2010. This figure is available in colour online at www.georeview.ro.

The double mass plots made for the Siret River at the gauging stations considered for our study are presented in figure 2 and 3. For all the plots drawn the annual sediment load of the river, provides clear evidence of a reduction after the middle of the 1980's (1985 - 1986) when all the dams where constructed. However, in this case, the reduction in sediment load has occurred without a significant decrease in annual runoff and primarily reflects the trapping of sediment by the dams constructed on this river. The change in the sediment response of the river caused by the construction of these dams is clearly demonstrated by the double mass plot.
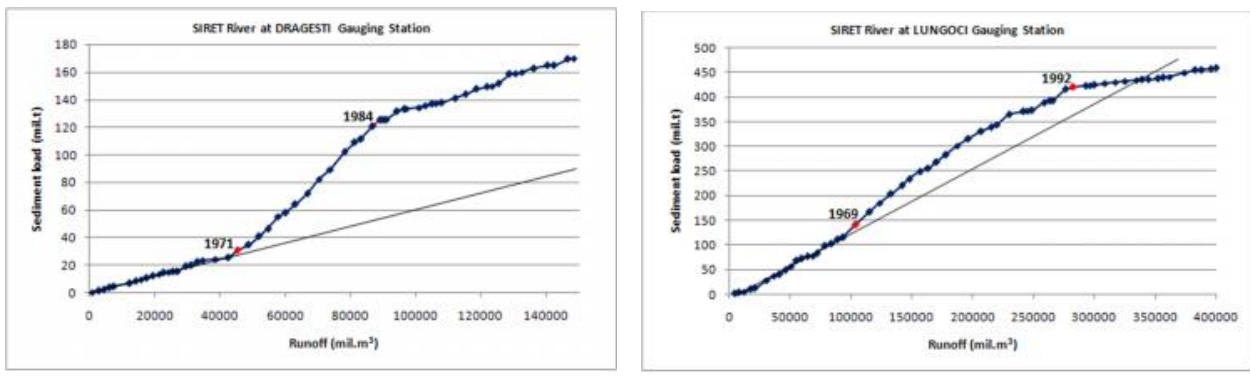

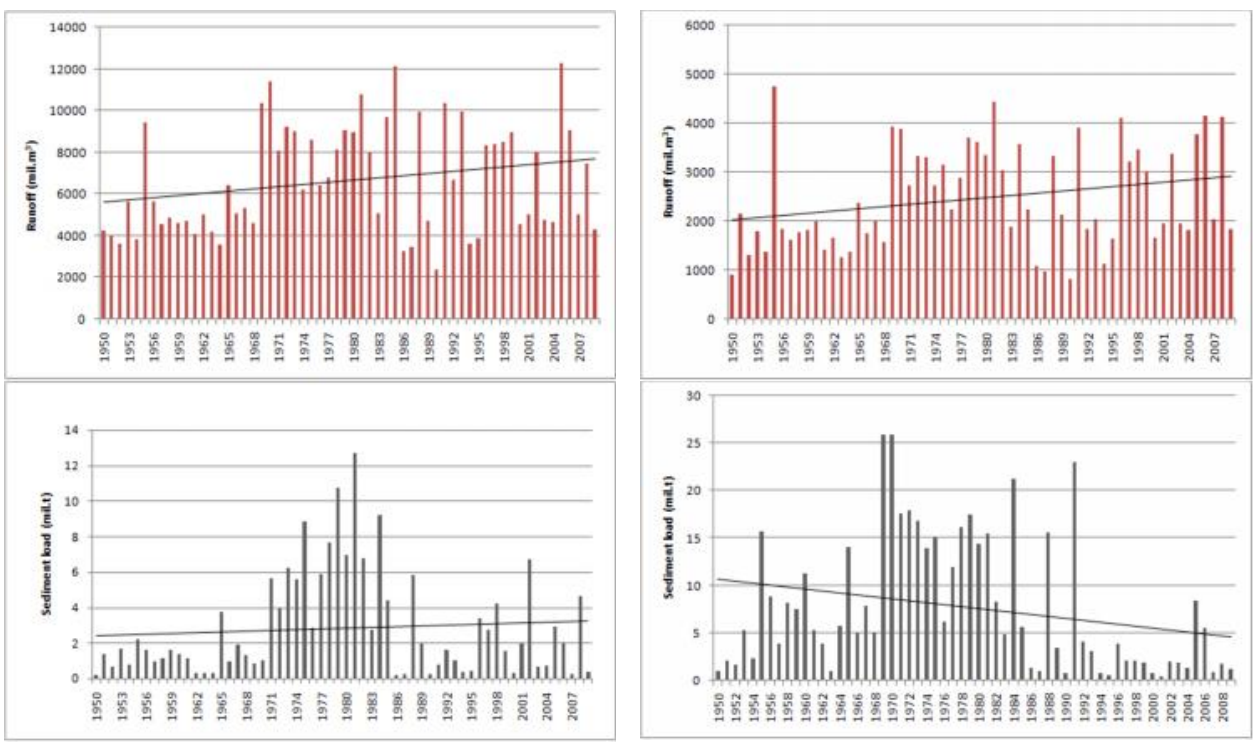

Figure 3. Double mass curves of sediments and runoff on the Siret River at Dragesti and Lungoci during 1950-2010. This figure is available in colour online at www.georeview.ro.

Table 2. TE and other characteristics of reservoirs in the Siret Basin

\begin{tabular}{|c|c|c|c|c|c|c|c|c|}
\hline River & Reservoir & $\begin{array}{l}\text { C-initial } \\
\left(\mathrm{mil} \mathrm{m}^{3}\right)\end{array}$ & $\begin{array}{c}\text { C-last } \\
\text { measured } \\
\left(\mathrm{mil} \mathrm{m}^{3}\right)\end{array}$ & $\begin{array}{c}\text { Year of } \\
\text { last } \\
\text { measure }\end{array}$ & $\begin{array}{c}\text { SV } \\
(t / y r)\end{array}$ & Source & $\begin{array}{l}\mathrm{TE} \\
\text { (\%) }\end{array}$ & $\begin{array}{l}\text { Method } \\
\text { TE }\end{array}$ \\
\hline Siret & ROGOJESTI & 38.4 & 34.9 & 2004 & 220000 & Siret Water Adm. & 85 & Brune \\
\hline Siret & BUCECEA & 8.73 & 4.97 & 2009 & 208889 & Siret Water Adm. & - & - \\
\hline Siret & GALBENI & 40 & 16 & 1988 & 2000000 & Siret Water Adm. & 86 & Brune \\
\hline Horodnic & HORODNIC & 1 & 0.55 & 2011 & 15000 & Siret Water Adm. & 87 & Brown \\
\hline Solca & SOLCA & 0.096 & 0.04 & 2002 & 3136 & Siret Water Adm. & 64 & Brown \\
\hline Somuzul Mare & SOMUZ II MOARA & 7.4 & 6 & 2011 & 41000 & Siret Water Adm. & 88 & Brown \\
\hline Bistrita & IZV MUNTELUI & 1123 & 1100 & 1998 & 570000 & Siret Water Adm. & 94 & Brune \\
\hline Bistrita & PANGARATI & 6.7 & 3.5 & 1987 & 139130 & N.Radoane, 2002 & - & - \\
\hline Bistrita & VADURELE & 5.6 & 4.96 & 1982 & 40000 & N.Radoane, 2002 & - & - \\
\hline Bistrita & B. DOAMNEI & 10 & 7.28 & 1990 & 340000 & N.Radoane, 2002 & - & - \\
\hline Bistrita & RACOVA & 8.6 & 4.27 & 1983 & 206190 & Olariu, 1992 & - & - \\
\hline Bistrita & GARLENI & 5.1 & 3.81 & 1982 & 75882 & Olariu, 1992 & - & - \\
\hline Bistrita & LILIECI & 7.4 & 6.61 & 1983 & 46471 & Olariu, 1992 & - & - \\
\hline Bistrita & BACAU & 7.4 & 6.04 & 1986 & 68000 & Olariu, 1992 & - & - \\
\hline Uz & POIANA UZULUI & 90 & 85.6 & 2009 & 191304 & Olariu, 1992 & 97 & Brune \\
\hline Tazlau & BELCI & 12.5 & 4.5 & 1991 & 350000 & Olariu, 1992 & 74 & Brune \\
\hline Barlad & PUSCASI & 17.2 & 6.65 & 1998 & 422000 & Purnavel, 1999 & 97 & Brown \\
\hline Barlad & ANTOHESTI & 0.22 & 0.13 & 1995 & 8182 & Purnavel, 1999 & 48 & Brown \\
\hline Barlad & GAICEANA & 0.41 & 0.24 & 1995 & 15455 & Purnavel, 1999 & 59 & Brown \\
\hline Barlad & CUIBUL VULTURILOR & 9.5 & 6.4 & 1992 & 221429 & Purnavel, 1999 & 76 & Brown \\
\hline Barlad & RAPA ALBASTRA & 10.6 & 8.5 & 1993 & 150000 & Purnavel, 1999 & 98 & Brown \\
\hline Barlad & SOLESTI & 52.7 & 52.1 & 1985 & 54545 & Purnavel, 1999 & 91 & Brown \\
\hline
\end{tabular}

On sediment retention capacity in the reservoirs, we calculated trap efficiency (TE) for some lakes where we had dates and where their position in the basin allowed us (see chapter 2 of this paper). TE was calculated as mentioned above in two ways (Brown method, Brune 
method). Values of this parameter are between $42-98 \%$. Wide spread of ratios can be attributed to high number of factors that influence this parameter (Table 2).

\section{Discussion}

Verstraeten and Poesen (2000), citing Heinemann (1981) indicate that TE of reservoirs is dependent on several parameters. Since TE is dependent on the amount of sediment deposited, parameters controlling the sedimentation process are very important. Therefore, the particle-size distribution of the incoming sediments controls TE in relation to retention time (the average time the incoming runoff remains in the reservoir). Coarser material will have a higher settling velocity, and less time is required for it to be deposited. Very fine material, on the other hand, will need long retention times to deposit. The particle-size distribution of the incoming sediment is dependent on the soils in the catchment that are being eroded and on the sediment delivery processes. The retention time of a reservoir is related to the characteristics of the inflow hydrograph and the geometric characteristics of the reservoirs or pond, including storage capacity, shape and outlet topography. The location of the principal spillway can also control the retention time. If located at the bottom, the water will flow out directly while, if it is located at the top of the embankment, the runoff water will, first, have the opportunity to mix with the water already present in the reservoir. The size of the spillway (which regulates the discharge) must be taken into account. Permanent poop storage (in contrast to completely dry reservoirs) also controls the average retention time (Verstraeten and Poesen, 2000).

From the controlling factors mentioned by Verstraeten and Poesen (2000), unfortunately we don't have more conclusive data than the capacity of reservoirs. The correlation from figure 4 between initial capacity of reservoirs considered $\left(\mathrm{m}^{3}, \mathrm{n}=14\right)$ and trap efficiency (TE \%) has a coefficient of determination of approximately 0.600 , which indicates that the capacity of the reservoirs explains almost $60 \%$ of the variations of TE. In reservoirs with higher capacity the values approach to $100 \%$ while in small reservoirs, the value of TE is decreasing (Brown, 1943; Brune, 1953).

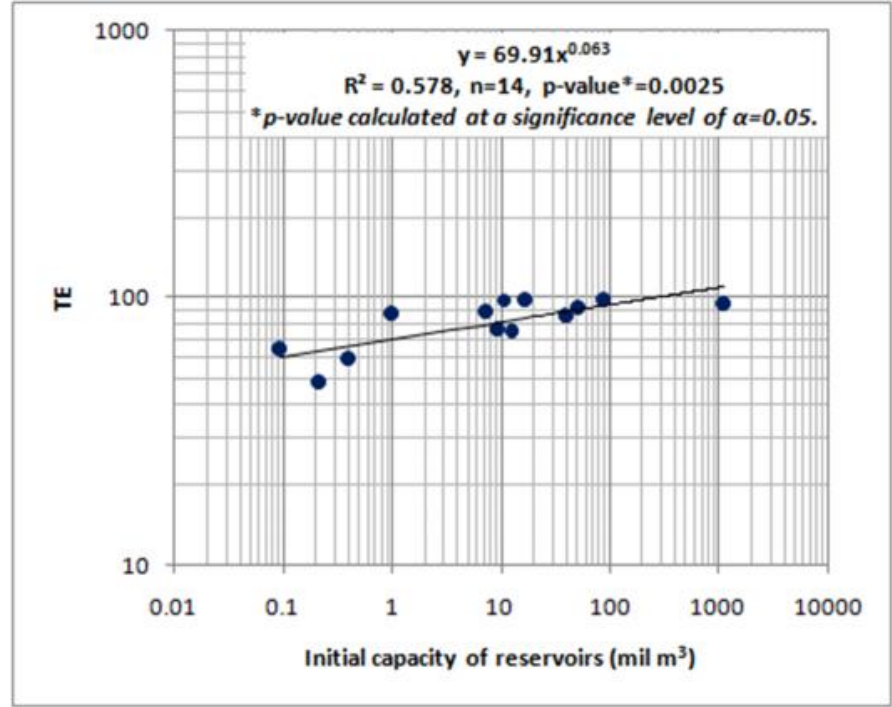

Figure 4. Correlation between TE and capacity of reservoirs in the Siret Basin. 
The relation from figure 4 was tested with Sigma Plot software - Function Statistics. The results of the analyses indicate that the relationship is statistical significant at p-value of 0.0025 which is lower than the significance level $\alpha(\alpha=0.05)$.

The relation from figure 4 indicates that the capacity of reservoirs is a very important controlling factor in retaining and silting the sediments transported by the rivers through the reservoirs. However, the lack of any other information regarding other controlling factor at the moment makes the analyses of the TE factor impossible. Data regarding incoming sediment characteristics (particle size distribution), inflow characteristics (runoff volume, peak discharge, base flow) and pond characteristics (pond typology, surface area, shape, outlet dimension, outlet type, location of the outlet, initial storage volume) need to be obtain and gathered together for a more accurate analyses.

Trap efficiency of the reservoirs is an important parameter in the analysis of sedimentation in the reservoirs and thus the transport of sediments in a river basin (Verstraeten et. al, 2006; Vanmaercke et.al, 2011). Although the complexity of this parameter determined by many controlling factors control as numerous authors mentioned (Brown, 1943; Brune, 1953; Heinemann, 1981; Verstraeten and Poesen, 2000) complicate this parameter calculation and theoretical models are more accurate in calculating TE, both Brown and Brune have adapted an empirical model that facilitates more computing TE (equations 1 and 2). These two formulas (equation 1 and 2 ) were used also by us for TE calculation in this paper.

\section{Conclusions}

Siret Basin is one of the most developed river basins in Romania in terms of reservoirs. A detailed analysis on this parameter (TE) provides an overview of the process of sedimentation in reservoirs. TE values can then be used in the calculation for SY upstream reservoirs. The calculated values for the reservoirs for which we had data in the Siret Basin vary between 42 $98 \%$. This correlates well with the capacity of reservoirs $\left(r^{2}=0.578, p\right.$-value $\left.=0.0025, \alpha=0.05\right)$. For reservoirs with large volumes TE value approaches $100 \%$, while for those with lower volumes the value reduces.

Unfortunately the lack of a more extensive database on the controlling factors of TE made it impossible a complete analysis of this process. However, this paper is intended as a starting point for further analysis on the TE and the reservoir silting which should result in a prediction model for sediment yield in the Siret Basin.

\section{Acknowledgements}

This paper has been financially supported within the project entitled „Doctorate: an Attractive Research Career", contract number POSDRU/107/1.5/S/77946, co-financed by European Social Fund through Sectorial Operational Programme for Human Resources Development 2007-2013. Investing in people!". 


\section{References}

Apopei N., Ichim I., Rădoane M., Pantazi E. 1988. Analiza debitelor lichide şi solide în bazinul hidrografic al râului Trotuş pentru evaluarea colmatării acumulării Adjud. Lucrările celui deal II-lea Simpozion „Provenienţa şi Efluenţa Aluviunilor”, Piatra Neamţ.

Brown C.B. 1943. Discussions of Sedimentation in reservoirs, by J. Witzig. Transactions of the American Society of Civil Engineers 69, 1493-1500.

Brune G.M. 1953. Trap efficiency of reservoirs.Transactions of the American Geophysical Union 34, 407-18.

Ciaglic V., Vornicu P., Stefan A., Rudnic I., Micu I. 1973. Contribuţii la cunoaşterea fenomenului de colmatare a lacului de acumulare Pângăraţi. Hidrobiologia 14.

Curchill M.A. 1948. Discussion of analysses and use of reservoir sedimentation data. by L.C. Gottschalk in Proceedings of the federal interagency sedimentation conference, Denver, Colorado, Washington, DC: US Geological Survey, 139-140.

de Vente J., Poesen J., Arabkhedri M., Verstraeten G. 2007. The sediment delivery problem revisited. Progress in Physical Geography, 31, 2, 155-178.

Dăscălescu N. 2000. History of dam construction in Romania. Romanian National Comitee on Large Dams, Bucharest, pp. 16-26.

Gâștescu P., Driga B., Sandu M. 2003. Lacurile de baraj antropic - între necesitate şi modificări ale mediului. în vol. Riscuri şi catastrofe, vol. II, editor V. Sorocovschi, Casa Cărţii de Ştiinţă, Cluj Napoca.

Heinemann H.G. 1981. A new sediment trap efficency curve for small reservoirs. Water Resources Bulettin 17, 825-30.

Ichim I., Rădoane M. 1986. Efectul barajelor în dinamica reliefului. Editura Academiei, Bucureşti.

lonescu F. 1980. Consideraţii privind colmatarea acumulărilor. Hidrotehnica 25 (12), 272-277.

Olariu P. 1992. Impactul antropic asupra regimului scurgerii apei şi aluviunilor în bazinul hidrografic Siret. Lucr. IV Simpozionului PEA, pp.121-130.

Olariu P., Gheorghe D. 1999. The effects of human activity on land erosion and suspended sediment transport in the Siret hydrographic basin, in Vegetation, land use and erosion processes (editat I. Zăvoianu, D.E. Walling, P. Şerban). Institutul de Geografie, 40-50, Bucureşti.

Olariu P., Obreja F., Obreja I. 2009. Unele aspecte privind tranzitul de aluviuni din bazinul hidrografic Trotuş şi de pe sectorul inferior al râului Siret în timpul viiturilor excepţionale din anii 1991 şi 2005. Analele Universităţii „Ştefan cel Mare” Suceava, Sectiunea GEOGRAFIE ANUL XVIII.

Pricop A., Nicolau A., Leu D. 1988. Studiu privind influenţa unor factori cauzali asupra colmatării lacurilor de acumulare din bazinul hidrografic Bahlui. Lucr. Celui de al II-lea Simpozion PEA, pp.114-120.

Purnavel Gh. 1999. Cercetari privind efectul lucrărilor de amenajare a formaţiunilor torenţiale, aflate în zona de influenţă excesivă a lacurilor de acumulare, asupra procesului de colmatare a acestora, cu referire la Podişul Central Moldovenesc. Rez. Tezei de Doctorat, Universitatea Tehnică "Gh. Asachi" laşi.

Rădoane M., Rădoane N. 2005. Dams, sediment sources and reservoir silting in Romania. Geomorphology 71, 112-125. 
Rădoane N. 2002. Geomorfologia bazinelor hidrografice mici. Editura Universitatii din Suceava.

Rădoane N., Rădoane M. 2004. Lacurile de baraj din bazinul râului Siret. Analele Universitătii "Ştefan cel Mare" Suceava, Secţiunea Geografie, anul XIII, 2004.

Roşca D. 1987. Cercetări complexe asupra colmatării lacurilor de acumulare. Lucr. Simpozionului „Provenienţa şi Efluenţa Aluviunilor”, Piatra Neamţ, pp. 63-70.

Roşca D., Miţurcă Ed. 1988. Lacurile de acumulare, factori de control al producţiei de aluviuni. Lucrările celui de-al II-lea Simpozion „Provenienţa şi Efluenţa Aluviunilor”, Piatra Neamţ.

Roşca D., Teodor S. 1990. Influenţa lacurilor de acumulare asupra transporturilor de aluviuni. Lucrările celui de-al III-lea Simpozion „Provenienţa şi Efluenţa Aluviunilor”, Piatra Neamţ.

Scorţov F., Armencea Gh. 1992. Implicaţii ale fenomenului de sedimentare în proiectarea lacurilor de acumulare. Lucrările celui de-al IV-lea Simpozion „Provenienţa şi Efluenţa Aluviunilor”, Piatra Neamţ.

Syvitski J.P.M., Peckham S.D., Hilberman R., Mulder T. 2003. Predicting the terrestrial flux of sediment to the global ocean: a planetary perspective. Sedimentary Geology 162: 5-24.

Syvitski J.P.M., Vorosmarty C.J., Kettner A.J., Green P. 2005. Impact of the Human on the Flux of Terrestrial Sediment to the Global Coastal Ocean. Science 308: 376-380.

Syvitski J.P.M., Milliman J. 2007. Geology, Geography and Human Battle for Dominance over the Delivery of Fluvial Sediment to the Coastal Ocean. The Journal of Geology 115: 1-19.

Şerban P., Teodor S. 1992. Colmatarea lacurilor de acumulare din România. Lucrările celui de-al IV-lea Simpozion „Provenienţa şi Efluenţa Aluviunilor”, Piatra Neamţ.

Újvari I. 1972. Geografia apelor României. Ed. Științifică, București.

Vanmaercke M., Poesen J., Verstraeten G., de Vente J., Ocakoglu F. 2011. Sediment yield in Europe: Spatial patterns and scale dependency. Geomorphology, 130, 3-4, 142-161.

Vanoni V.A. 1977. Sedimentation Engineering. ASCE manuals and reports on engineering practice No.54, 745.

Verstraeten G., Poesen J. 2000. Estimating trap efficency of small reservoirs and ponds: methods and implications for the assessment of sediment yield. Progress in Physical Geography 24(2), 219-251.

Verstraeten G., Poesen J. 2002. Using sediment deposits in small ponds to quantify sediment yield from small catchments: possibilities and limitations. Earth surface processes and landforms, 27, 13, 1425-1439.

Verstraeten G., Bazzofi P., Lajczack A., Rădoane M., Rez F., Poesen J., de Vente J. 2006. Reservoir and pond sedimentation in Europe, Soil Erosion in Europe. Wiley and Sons, Ltd.

Walling D.E. 1983. The sediment delivery problem. J.Hydrol. 65, 209-237.

Walling D.E. 1997. The response of sediment yields to environmental change. Human impact on erosion and sedimentation. Proceedings of Rabat Symposium S6, April 1997.

Walling D.E. 1999. Linking land use, erosion and sediment yields in river basins. Hydrobiologia 410, 223-240.

Walling D.E. 2009. The Impact of global change on erosion and sediment transport by rivers: current progress and future challenges. The United Nations World Water Assessment Programme - Scientific paper.

Zavati V., Giurma I. 1982. Cercetări privind colmatarea unor lacuri de acumulare din bazinul hidrografic Bahlui. Hidrotehnica 27 (2), 21-29. 